\title{
Comparison of VIP-induced electrolyte secretion at three levels in rat small intestine
}

\author{
AR Chikhlssa *, A Gharzouli **, G Charpin 1, \\ M Descroix-Vagne 1, D Pansu ${ }^{* \star *}$
}

Hôpital E Herriot, Pavillon H bis, Unité de Recherche INSERM U 45

et École Pratique des Hautes Études, 69437 Lyon Cedex 03, France

(Received 24 May 1991; accepted 18 December 1991)

\begin{abstract}
Summary - Duodenal, jejunal and ileal loops were prepared and an iso-osmotic test solution injected, containing $80 \mathrm{mM} \mathrm{Na}^{+}, 5 \mathrm{mM} \mathrm{K}^{+}, 1.2 \mathrm{mM} \mathrm{Ca}^{2+}, 77 \mathrm{mM} \mathrm{Cl}^{-}, 10 \mathrm{mM} \mathrm{HCO}_{3}{ }^{-}$and $136 \mathrm{mM}^{2}$ mannitol. ${ }^{14} \mathrm{CPEG} 4000$ was used as a non-absorbable marker and ${ }^{36} \mathrm{Cl}$ was added to measure the bidirectional fluxes. During the $60-\mathrm{min}$ in vivo incubation time, the duodenum actively secreted bicarbonate, a virtually zero flux in the jejunum was observed, whereas the ileum absorbed water and chloride and secreted bicarbonate. The response to the perfused doses of 0.15 to $2.4 \mathrm{nmol}-100$ $\mathrm{g}^{-1} \cdot \mathrm{h}^{-1}$ of VIP (vasoactive intestinal peptide) differed qualitatively and quantitatively in the $3 \mathrm{seg}$ ments: VIP increased bicarbonate secretion and induced chloride secretion in the duodenum, induced chloride secretion in the jejunum without changing bicarbonate minimal influx, induced bicarbonate secretion and suppressed chloride absorption in the ileum. The minimal dose required was lower in the duodenum $\left(0.3 \mathrm{nmol}-100 \mathrm{~g}^{-1} \cdot \mathrm{h}^{-1}\right)$ than in the jejunum and ileum $\left(1.2 \mathrm{nmol} \cdot 100 \mathrm{~g}^{-1} \cdot \mathrm{h}^{-1}\right)$. The functional heterogeneity of the small intestine was clearly demonstrated after VIP stimulation.
\end{abstract}

bicarbonate / chloride / intestinal secretion / sodium / rat / VIP

Résumé - Comparaison de la sécrétion induite par le VIP (peptide intestinal vasoactif) à trois niveaux de l'intestin grêle chez le rat. Des anses duodénales, jéjunales et iléales ont été constituées chez le rat anesthésié et remplies avec un $\mathrm{m} /$ de solution test contenant $80 \mathrm{mM}$ de $\mathrm{Na}^{+}$, $5 \mathrm{mM}$ de $\mathrm{K}^{+}, 1,2 \mathrm{mM}$ de $\mathrm{Ca}^{2+}, 77 \mathrm{mM}$ de $\mathrm{Cr}, 10 \mathrm{mM}$ de $\mathrm{HCO}_{3}^{-}$et $136 \mathrm{mM}$ de mannitol. Le ${ }^{14} \mathrm{CPEG} 4000$ a été utilisé comme marqueur non absorbable du mouvement d'eau et du ${ }^{36} \mathrm{Cl}$ a été ajouté pour évaluer les flux bidirectionnels. Au niveau des anses témoins, le duodénum a sécrété activement le bicarbonate, le flux électrolytique était nul dans le jéjunum, l'iléon a absorbé du chlore et sécrété du bicarbonate. La réponse à la perfusion IV de VIP aux doses de 0,15 à 2,4 nmol/100 $g \bullet h$ a confirmé les différences fonctionnelles aux trois niveaux explorés. Le VIP a augmenté la sécrétion de bicarbonate et induit une sécrétion de chlore dans le duodénum, induit une sécrétion de chlore dans le jéjunum, supprimé l'absorption de chlore et d'eau et augmenté la sécrétion de bicar-

\footnotetext{
* Present address: University of Damascus, Laboratory of Physiology, Faculty of Medicine, Damascus, Syria

** Present address: Institut de Biologie, University de Sétif, 19000 Sétif, Algeria

${ }^{* * *}$ Correspondence and reprints
} 
bonate et d'eau dans l'iléon. La dose minimale active a été plus basse dans le duodénum (0,3 nmol/ $100 \mathrm{~g} \cdot \mathrm{h})$ que dans le jéjunum et l'iléon (1.2 nmol/100 g•h). Le VIP induit une activation de la sécrétion anionique associée à une inhibition de l'absorption.

bicarbonate / chlore / sécrétion intestinale / rat / sodium / VIP

\section{INTRODUCTION}

The stimulation of intestinal secretion by the vasoactive intestinal peptide (VIP) was described shortly after the discovery of the peptide (Barbezat and Grossman, 1971) and has been largely documented, but no simultaneous study on the effects of this peptide on the 3 segments of the small intestine - duodenum, jejunum and ileum has been published. Studies on the duodenal response to VIP in the rat reported the induction of bicarbonate secretion in the superficial epithelium (Isenberg et al, 1984) as well as in Brunner's glands (Kirkegard et al, 1984) but did not explore the movement of other ions. In the jejunum and ileum, the increase in water secretion has been shown in the dog (Barbezat, 1973; Mailman, 1978), rabbit (Camilleri et al, 1981) and cat (Eklund et al, 1981) using isolated loop perfusion in man by triple lumen tube perfusion (Krejs et al, 1980), in rat (Coupar, 1976) using the in situ ligated loop technique and in pig, in which a watery diarrhea was induced (Modlin et al, 1978). The anionic secretion differed according to the species: in the jejunum of the dog VIP induced an active chloride and bicarbonate secretion (Krejs et al, 1978) but a chloride secretion in man (Krejs et al, 1980). In the ileum a bicarbonate secretion was associated with the suppression of chloride absorption in man (Krejs, 1982) while chloride was the only secreted anion in the rabbit (Schwartz et al, 1974). The present study was undertaken to document regional heterogeneity in intestinal transport function and to explore the outcome of such heterogeneity during the same stimulation by VIP at the various levels of the intestine.

\section{MATERIALS AND METHODS}

Male Sprague-Dawley rats, purchased from Iffa Credo (L'Arbresle, France) were fed on standard chow (A04, UAR, Villemoisson-sur-Orge, France) until their body weight averaged $200 \pm$ $25 \mathrm{~g}$. Thirty-six $\mathrm{h}$ before the experiment, food was withdrawn, and the animals were allowed free access to water. On the day of the experiment, the animals were anesthetized ( $4 \mathrm{mg}$ sodium pentobarbital / $100 \mathrm{~g} \mathrm{BW}$ ) and an intravenous infusion of VIP in $0.9 \%$ saline solution was initiated via a jugular catheter. The infusion rate was $0.05 \mathrm{ml} / \mathrm{min}$. Doses of VIP (MW = 3326 , GIH Res Lab, Karolinska Institutet, Stockholm, Sweden) were $0.15,0.30,0.60,1.2$ and 2.4 $\mathrm{nmol} \cdot 100 \mathrm{~g}^{-1} \cdot \mathrm{h}^{-1}$, respectively.

Three $10-\mathrm{cm}$ intestinal loops were prepared for each animal. Ligation for the duodenal loop began at the pylorus, for the jejunal loop $3 \mathrm{~cm}$ distal to the ligament of Treitz, for the ileal loop $10 \mathrm{~cm}$ proximal to the ileo-caecal junction. Only the ileal segment that still contained some food residues was rinsed with $0.9 \% \mathrm{NaCl}$. The hepatobiliary canal was also tied off. One $\mathrm{ml}$ of the test solution was injected into each loop with the aid of a calibrated syringe and an additional ligature was placed proximal to the injection site to avoid leakage of the injected solution. The ligated loops were placed back into the abdominal cavity which was then sutured. Sixty min later, the animals were killed by an intravenous injection of air, the loops were exteriorized, cut proximally to the outside of the ligature. Loop contents were collected, centrifuged and the supernatant was measured and used for the determinations. 
Preliminary experiments indicated that when $80 \mathrm{mM} \mathrm{NaCl}$ and $140 \mathrm{mM}$ mannitol solution was injected, neither electrolytes nor water moved transmurally in the jejunum. These concentrations were then made the basis of a solution that contained $70 \mathrm{mM} \mathrm{NaCl}, 5 \mathrm{mM} \mathrm{KCl}, 1.2 \mathrm{mM}$ $\mathrm{CaCl}_{2}, 10 \mathrm{mM} \mathrm{HNaCO}, 136 \mathrm{mM}$ mannitol, $\mathrm{pH}$ 8.1. ${ }^{36}$ Chloride in $\mathrm{HCl}$ (NEN France) was added at a concentration of $0.05 \mu \mathrm{Ci} / \mathrm{ml}$ as an influx marker. Tritiated polyethylene glycol 4000 ( ${ }^{3} \mathrm{HPEG} 4000$, NEN France $0.05 \mu \mathrm{Ci} / \mathrm{ml}$ ) mixed with $5 \mathrm{~g} / \mathrm{l}$ of cold PEG 4000 was used as a nonabsorbable marker. Only those experiments where recovery of labeled PEG 4000 was $\geq 88 \%$ were analyzed. Recovery of ${ }^{14} \mathrm{C}$ mannitol from the lumen was controlled in a complementary study and exceeded $90 \%$.

The VIP concentration in the blood before and after intravenous perfusion and in the catheter was measured by radioimmunoassay (Chayvialle et al, 1980). $\mathrm{Na}^{+}$and $\mathrm{K}^{+}$content were determined by flame photometry, $\mathrm{Cl}^{-}$by coulometric titration, bicarbonate by alkali-acid titration and radioactivity by liquid scintillometry.

Comparisons between control and experimental situations were based on means derived from 7-14 loops. Net absorption from the lumen was expressed as a negative and net secretion as a positive value. Statistical analyses of differences were carried out with Student's $t$-test, or the Mann-Whitney test. Linear relationships were derived by least-squares analysis.

\section{RESULTS}

\section{Control conditions}

In the duodenum, an efflux of sodium, chloride and bicarbonate with $0.24 \mathrm{ml}$ of water was observed (table 1). The final luminal concentration of sodium and bicarbonate was increased significantly (table II). The final $\mathrm{pH}$ was 7.4. In the jejunum, there was an efflux of sodium and chloride, an influx of bicarbonate with almost no water movement. The luminal concentration of bicarbonate decreased from $10 \mathrm{mM}$ to 6.7 $\pm 0.4 \mathrm{mM}$. $\mathrm{pH}$ decreased from 8.1 to 6.6 . In the ileum, a significant influx of water and chloride and an efflux of bicarbonate was observed. These fluxes induced a significant decrease in luminal chloride concentration and a significant increase in luminal bicarbonate concentration. The final luminal $\mathrm{pH}$ was 8.0. In the 3 intestinal segments, the bidirectional fluxes were evaluated by the ${ }^{36} \mathrm{Cl}$ influx which constituted $86 \%$ of the ${ }^{36} \mathrm{Cl}$ instilled in the duodenum and jejunum and $93 \%$ of the ${ }^{36} \mathrm{Cl}$ instilled in the ileum. The calculated chloride efflux

Table I. Ionic and water fluxes in control rats.

\begin{tabular}{lccccccc}
\hline Segment & $n$ & $\begin{array}{c}\text { Water } \\
(\mathrm{ml})\end{array}$ & $\begin{array}{c}\mathrm{Na} \\
(\mu \mathrm{Eq})\end{array}$ & $\begin{array}{c}K \\
(\mu \mathrm{Eq})\end{array}$ & $\begin{array}{c}\mathrm{Cl} \\
(\mu \mathrm{Eq})\end{array}$ & $\begin{array}{c}\mathrm{HCO}_{3} \\
(\mu \mathrm{Eq})\end{array}$ & $\begin{array}{c}36 \mathrm{Cl} \text { influx } \\
(\% \text { injected })\end{array}$ \\
\hline Duodenum & 14 & $0.24 \pm 0.07$ & $44 \pm 12$ & $2.6 \pm 0.6$ & $20 \pm 10$ & $16 \pm 3$ & 86 \\
Jejunum & 14 & $0.02 \pm 0.02$ & $13 \pm 4$ & $2.2 \pm 0.8$ & $6 \pm 4$ & $-3 \pm 0.3$ & 86 \\
lleum & 13 & $-0.13 \pm 0.03^{*}$ & $-10 \pm 5$ & $-1.2 \pm 1.2^{*}$ & $-55 \pm 2^{* \star}$ & $38 \pm 5^{* *}$ & 93 \\
\hline
\end{tabular}

Fluxes expressed per loop and per $\mathrm{h}$. Secretion is indicated by positive values, absorption by negative values. $M \pm$ SEM; * $P<0.05 ;{ }^{* *} P<0.01$, significantly different from fluxes in the duodenum and jejunum. 
Table II. Final luminal ionic concentration in control and VIP-treated rats.

\begin{tabular}{|c|c|c|c|c|c|c|c|}
\hline \multirow[t]{2}{*}{ Ion } & \multirow{2}{*}{$\begin{array}{c}\text { Test } \\
\text { solution } \\
\text { (mM) }\end{array}$} & \multicolumn{2}{|c|}{$\begin{array}{l}\text { Duodenum } \\
\text { (mM) }\end{array}$} & \multicolumn{2}{|c|}{$\begin{array}{l}\text { Jejunum } \\
\text { (mM) }\end{array}$} & \multicolumn{2}{|c|}{$\begin{array}{l}\text { Ileum } \\
(\mathrm{mM})\end{array}$} \\
\hline & & $T$ & VIP & $T$ & VIP & $T$ & VIP \\
\hline $\mathrm{Na}^{+}$ & 80 & $96.7 \pm 4.0^{*}$ & $130.6 \pm 1.0^{* * *}$ & $90.4 \pm 1.4^{*}$ & $115.0 \pm 2.0^{* * *}$ & $79.3 \pm 2.7$ & $106.8 \pm 3.7^{* * *}$ \\
\hline $\mathrm{Cl}^{-}$ & 77.6 & $76.0 \pm 4.0$ & $96.7 \pm 1.6^{\star \star \star}$ & $81.8 \pm 2.4$ & $109.4 \pm 2.0^{* * *}$ & $25.8 \pm 1.3^{*}$ & $58.9 \pm 1.5^{* * *}$ \\
\hline $\mathrm{HCO}_{3}^{-}$ & 10 & $20.2 \pm 1.4^{*}$ & $38.8 \pm 0.6^{\star \star \star}$ & $6.7 \pm 0.4$ & $8.0 \pm 0.4^{* *}$ & $53.9 \pm 3.3^{*}$ & $56.4 \pm 1.0$ \\
\hline $\mathrm{K}^{+}$ & 5 & $6.2 \pm 0.3$ & $8.4 \pm 0.8$ & $6.6 \pm 0.3$ & $6.0 \pm 0.7$ & $4.6 \pm 0.2$ & $5.3 \pm 0.2$ \\
\hline
\end{tabular}

$\mathrm{M} \pm \mathrm{SEM} ; \mathrm{T}=$ control loops; $n=14 ;{ }^{*} P<0.05$ significantly different from the test solution; VIP $=$ rats perfursed with 2.4 nmot $100 \mathrm{~g}^{-1} \cdot \mathrm{h}^{-1}, n=7 ;{ }^{* *} P<0.05 ;{ }^{* * *} P<0.01$, significantly different from the final concentration in control loops.

$\left({ }^{36} \mathrm{Cl}\right.$ influx $-{ }^{35} \mathrm{Cl}$ net absorption) was significantly lower in the ileum than in the duodenum and jejunum. Potassium was secreted in the duodenum and jejunum and absorbed in the ileum.

The doses of VIP ranged from 0.15 to $2.4 \mathrm{nmol} \cdot 100 \mathrm{~g}^{-1} \cdot \mathrm{h}^{-1}$, VIP adhesion to the flask and catheter walls was $70 \%$ at the low dose, $30 \%$ at the high dose. The basal VIP blood concentration was 1.5-3.6 10-12 $\mathrm{M}$ at the beginning of the experiment and reached $5.310^{-11} \mathrm{M}$ and $5.710^{-9} \mathrm{M}$ after the low and high dose respectively.

In the duodenum (fig 1) VIP increased the secretion of sodium, chloride, bicarbonate and water. The increase was significant with doses of $\geq 0.3 \mathrm{nmol} \cdot 100 \mathrm{~g}^{-1} \cdot \mathrm{h}^{-1}$. The response to VIP was dependent on the log of the dose. In the jejunum the increase in sodium and chloride secretions was dose-dependent for the doses of 0.6 nmol-100 $\mathrm{g}^{-1} \cdot \mathrm{h}^{-1}$. In the ileum the absorption reverted to secretion for water and sodium at doses of 1.2 and $2.4 \mathrm{nmol}$ and for chloride at the dose of $2.4 \mathrm{nmol} . \mathrm{h}^{-1} / 100 \mathrm{~g}$.
At every level of the intestine final electrolyte concentrations increased (table II). Chloride influx, expressed as ${ }^{36} \mathrm{Cl}$ absorption was inhibited in a dose-dependent manner and decreased to 51,70 and $66 \%$ in the duodenum, jejunum and ileum respectively with the highest dose. On the other hand, chloride efflux was significantly increased.

The potassium secretion augmented with the dose of VIP. The final concentration attained $8 \mathrm{mM}$ in the duodenum, did not change in the jejunum and the ileum, while the potassium flux paralleled the water flux (table II).

\section{DISCUSSION}

The in vivo ligated loop was shown to be a closed system where anionic and cationic concentrations equilibrated during the 60 min study. The low concentrations of sodium and chloride corresponded to the zero flux ion concentration (Fromm and Hegel, 

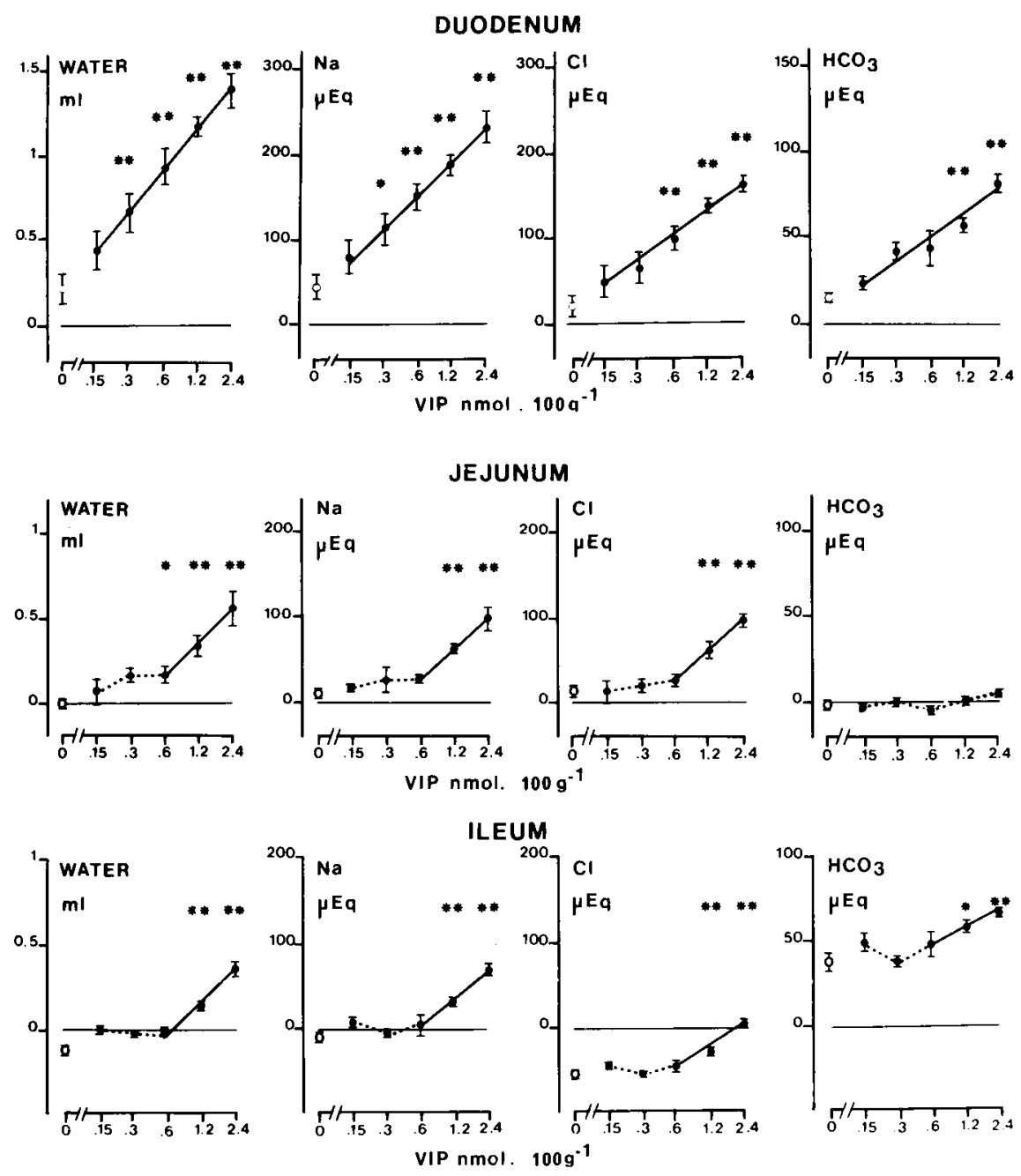

Fig 1. Effect of VIP on ion and water fluxes in the intestinal ligated loops. Positive values indicate a secretion. Doses in nmol $100 \mathrm{~g}^{-1} \cdot \mathrm{h}^{-1} ; n=7$ for each treated group, $n=14$ for control groups. ${ }^{*} P<0.05 ;{ }^{* *} P<0.01$ compared with the control values. The linear relationship between log 10 dose and secretion was highly significant for the 5 doses tested in the duodenum, and for the 3 high doses tested in the jejunum and ileum.

1987) in the jejunum, ie the concentration where there is no net exchange of ions between the lumen and the blood when the osmolarity is maintained by the presence of mannitol in the test solution.
Heterogeneity of the small intestine was demonstrated in control animals. In the duodenum, an efflux of bicarbonate, sodium and chloride was observed. Sodium bicarbonate was secreted by both Brunner's 
glands and epithelial cells, since the bicarbonate flux was quantitatively higher than that measured in a duodenal loop prepared beyond the Brunner's gland region and dependent on epithelial cells only (7 $\mu \mathrm{mol} \cdot \mathrm{cm}^{-1} \cdot \mathrm{h}^{-1}$ ) (Heylings and Feldman, 1988). Such an efflux was active, since bicarbonate concentration in the efflux was $66 \mathrm{mM}$. The distension caused by the injected fluid was sufficient to induce vagal stimulation of the secretion (Nylander et al, 1987). In the jejunum, the steady state was characterized by the decrease of luminal $\mathrm{pH}$ to 6.6. This decrease was sufficient to dissociate bicarbonate and to permit the diffusion of $\mathrm{CO}_{2}$ from the lumen through the cell. In the ileum the net absorption of water, sodium and chloride created a high sodium gradient between the luminal ( 79.3 $\mathrm{mM})$ and serosal $(140 \mathrm{mM})$ fluid. The ligated loop model revealed characteristics that were in agreement with the physiological function of the small intestine: neutralization of gastric secretion in the duodenum, reabsorption of bicarbonate in the jejunum, water absorption in the ileum.

The response to VIP was observed with plasma concentrations (53 pM-5.7 nM) that were 10 to 1000 times higher than the physiologial concentration (a pmol range in our study), and parallelled the plasma concentration of immuoreactive VIP (1.5 nM) measured in patients suffering from a watery diarrhea syndrome induced by VIP-secreting tumors (Said and Faloona, 1975). The values were in the $K_{d}$ range $(1 \mathrm{nM})$ of the VIP receptors present in plasma membranes of rat enterocytes (Prieto et al, 1981) and corresponded to the estimated concentration of VIP created in the vicinity of intestinal cells by paracrine stimulation (Laburthe and Amiranoff, 1989).

A lower dose of VIP was required to induce a significant secretion of water and electrolytes in the duodenum than in the distal parts of the intestine. Since an equivalent number of VIP binding sites was found in epithelial cells obtained from the duodenum, jejunum and ileum (Prieto et al, 1981), the duodenal response to the low dose probably represented the bicarbonate secretion of Brunner's glands, known to respond to $0.27 \mathrm{pmol}$ VIP 100 $\mathrm{g}^{-1} \cdot \mathrm{h}^{-1}$ in the rat (Kirkegaard et al, 1984). Chloride concentration in the secreted fluid was $100 \mathrm{mM}$, ie near the systemic value, but the significant increase in luminal chloride concentration argued in favor of an active secretion. In the jejunum, the chloride secretion was active since the chloride concentration in the secreted fluid was 160 $\mathrm{mM}$. The absence of bicarbonate secretion was also observed in human jejunum (Krejs et al, 1980) but contrasted with the significant secretion of bicarbonate observed in the dog (Krejs et al, 1978). In the ileum, inhibition of basal absorption and water secretion are induced by VIP in all species: in the dog (Mailman, 1978), rat (Wu et al, 1979) and man (Krejs et al, 1980). Bicarbonate is the only anion secreted in rat and man (Krejs, 1982). The absence of bicarbonate secretion in the jejunum and of chloride secretion in the ileum was demonstrated in man under basal (Turnberg et al, 1970) and stimulated (Krejs, 1982) conditions. Our data demonstrate the similar anionic response in rat and in man.

A diagram of the fluxes is presented in figure 2, taking into account the action of recently identified exchangers and channels. In the duodenum a bicarbonate secretion from both epithelial cells and Brunner's glands is observed which depends on 3 mechanisms (Flemström, 1987): a furosemide sensitive $\mathrm{HCO}_{3}^{-} / \mathrm{Cl}^{-}$exchange, an active chloride-independent electrogenic $\mathrm{HCO}_{3}^{-}$secretion driven by a bicarbonatesensitive ATPase (Stiel et al, 1984), and diffusion through tight junctions. The simultaneous secretion of chloride and bicarbo- 


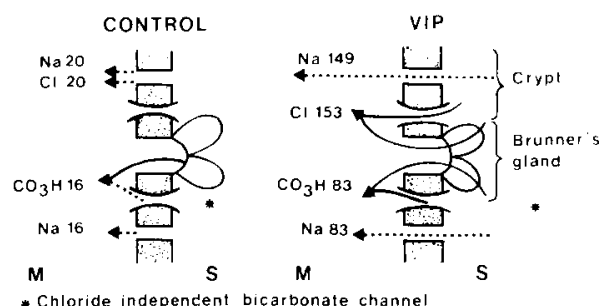

(A) DUODENUM

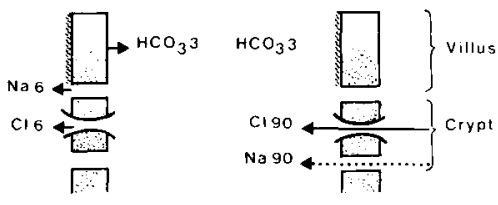

M
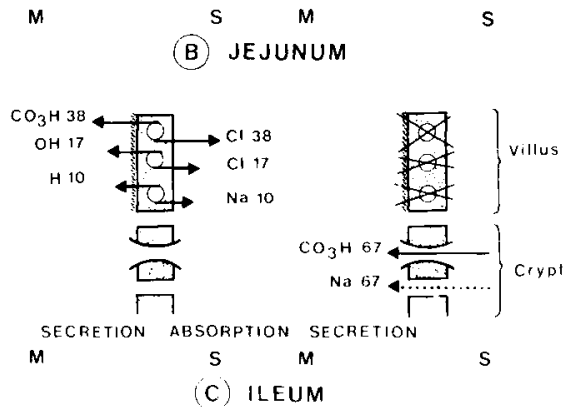

Fig 2. Suggested relationship between net fluxes and possible transport models. Fluxes are those measured in intestinal loops of control rats or rats perfused with $2.4 \mathrm{nmol} \cdot 100 \mathrm{~g}^{-1} \cdot \mathrm{h}^{-1}$ of VIP. Representation as used by Tai and Decker (1980). The drawing indicates crypt cells as the unique secretory cells; secretion may in fact occur in both crypt and villus cells (Stewart and Turnberg, 1989). The numerical values are the mean of the net fluxes in $\mu \mathrm{mol} / \mathrm{h}, \sigma=$ exchange;

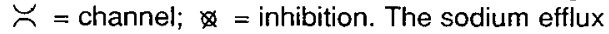
that follows the anionic secretion was described as a diffusion -------> over the paracellular path. A, Duodenum: the anionic active secretion pesent in the basal state is stimulated by VIP. B, Jejunum: control values are characterized by a zero flux, VIP activates the chloride channel. C, Ileum: absorption in control is the sum of the action of 3 exchangers, VIP suppresses absorption and activates bicarbonate secretion. nate confirmed that VIP activated both the chloride-independent bicarbonate secretion and a possible apical chloride channel. Evidence of bicarbonate secretion independent of chloride exchange was emphasized by the concomitant reduction in $36 \mathrm{Cl}$ influx from 86 to $49 \%$ of the quantity injected. In the jejunum the decrease in $\mathrm{pH}$ seems to be permitted by the coupled exchangers $\mathrm{Na}^{+} / \mathrm{H}^{+}$and $\mathrm{Cl}-/ \mathrm{CO}_{3} \mathrm{H}^{-}$in which the rate of cationic exchange largely exceeds that of the anionic exchange (Hopfer and Liedke, 1987). The VIP-induced chloride secretion depends on the activation of the apical chloride channel by CAMP. dependent protein kinases (Schwartz et al, 1974; Laburthe et al, 1979). In the ileum, the sodium-independent bicarbonate/ chloride exchange could mediate bicarbonate secretion and some of the chloride absorption (Alper, 1991) whereas the coupled exchangers $\mathrm{Na}^{+} / \mathrm{H}^{+}$and $\mathrm{Cl}-/ \mathrm{OH}^{-}$may allow the net absorption of sodium chloride and water (Liedke and Hopfer, 1982). The response to VIP is consistent with an inhibition of the absorptive processes located in mature cells, possibly through cAMP production (Eklund et al, 1987) and an activation of bicarbonate secretion. This interpretation is in keeping with the presence of VIP receptors throughout the crypt villus axis (Laburthe and Amiranoff, 1989).

In summary, VIP induces water secretion by stimulating anion secretion of both chloride and bicarbonate in the duodenum, chloride only in the jejunum, bicarbonate only in the ileum. The existence of 2 anionic secretions may depend on specific mechanisms, ie chloride channel and ATP dependent bicarbonate efflux; nevertheless, it raises the possibility of a unique anion-selective channel that is more permeable to one or the other anion depending on the epithelium (Sullivan and Field, 1991).

The in situ ligated loop technique differentiated the movement of ions at 3 levels 
of the intestine after administration of VIP. In the duodenum, the increase in bicarbonate and chloride secretion suggests an action on glandular and epithelial cells. In the jejunum, the action may concern chloride channels only. In the ileum, VIP may suppress absorption by villus cells and induce secretion by all cells, or only crypt cells. These findings confirm the plurality of the mechanisms regulating electrolyte secretion and absorption in the small intestine.

\section{ACKNOWLEDGMENTS}

This work was supported by a graduate student award to $\mathrm{ACl}$ from the UER de Biologie Humaine, Université Claude Bernard Lyon 1, grant 2418 from the Programme Régional RhôneAlpes de Recherche sur la Mucoviscidose, 69260 Charbonnières-les-Bains and grant 024930008 from the Caisse Nationale d'Assurance Maladie des Travailleurs Salariés. The authors thank $C$ Bernard for performing VIP radioimmunoassays and $\mathrm{J}$ Carew for reviewing the English manuscript.

\section{REFERENCES}

Alper SL (1991) The band 3-related anion exchanger (AE) gene family. Ann Rev Physiol $53,549-564$

Barbezat GO, Grossman MI (1971) Intestinal secretion: stimulation by peptides. Science $174,422-424$

Barbezat GO (1973) Stimulation of intestinal secretion by polypeptide hormones. Scand $J$ Gastroenterol (suppl 22) 8, 1-21

Camilleri M, Cooper BT, Adrian TE, Bloom SR, Chadwick VS (1981) Effect of vasoactive intestinal peptide and pancreatic polypeptide in rabbit intestine. Gut 22, 14-18

Chayvialle JA, Miyata M, Rayford PL, Thompson JC (1980) Effects of test-meal intragastric nutrients and intraduodenal bile on plasma concentrations of immunoreactive somatostatin and vasoactive intestinal peptide in dogs. Gastroenterology 75, 1124-1132
Coupar IM (1976) Stimulation of sodium and water secretion without inhibition of glucose absorption in the rat jejunum by vasoactive intestinal peptide (VIP). Clin Exp Pharmacol Physiol 3, 615-618

Eklund S, Brunsson I, Jodal M, Lundgren O (1987) Changes in cyclic 3'5'-adenosine monophosphate tissue concentration and net fluid transport in the cat small intestine elicited by cholera toxin, arachidonic acid, vasoactive intestinal polypeptide and 5-hydroxy tryptamine. Acta Physiol Scand 129, 115-125

Flemström G (1987) Gastric and duodenal mucosal bicarbonate secretion. In: Physiology of the Gastrointestinal Tract (Johnson LR, ed) Raven Press, New York, 2nd edn, ch 35, 1011-1053

Fromm M, Hegel U (1987) Net ion fluxes and zero flux limiting concentrations in rat upper colon and rectum during anesthesia-induced aldosterone liberation. Pflügers Arch 408, 185-193

Heylings JR, Feldman $M$ (1988) Basal and $\mathrm{PGE}_{2}$-stimulated duodenal bicarbonate secretion in the rat in vivo. Am J Physiol 255 (Gastrointest Liver Physiol 18) G470-G475

Hopfer U, Liedke CM (1987) Proton and bicarbonate transport mechanisms in the intestine. Ann Rev Physiol 49, 51-67

Isenberg $\mathrm{J}$, Wallin $\mathrm{B}$, Johansson $\mathrm{C}$, Smedfors B, Mutt V, Tatemoto K, Emas S (1984) Secretin, VIP, and PHI stimulate rat proximal duodenal surface epithelial bicarbonate secretion in vivo. Regul Pept 8, 315-320

Kirkegaard P, Olsen PS, Nexo E, Holst JJ, Poulsen SS, Fahrenkrug J, Hökfelt T, Christiansen $J$ (1984) Effect of vasoactive intestinal polypeptide and somatostatin on secretion of epidermal growth factor and bicarbonate from Brunner's glands. Gut 25, 1225-1229

Krejs GJ, Barkley RM, Read NW, Fordtran JS (1978) Intestinal secretion induced by vasoactive intestinal polypeptide, comparison with cholera toxin in the canine jejunum in vivo. J Clin Invest 61, 1337-1345

Krejs GJ, Fordtran JS, Bloom SR, Fahrenkrug J, Schaffalitzky de Muckadell $O B$, Fischer JE, Humphrey CS, O'Dorisio TM, Said SI, Walsh $\mathrm{JH}$, Shukles AA (1980) Effect of VIP infusion on water and ion transport in the human jejunum. Gastroenterology 78, 722-727 
Krejs GJ (1982) Effect of VIP infusion on water and electrolyte transport in the human intestine. In: Vasoactive Intestinal Peptide (Said Sl, ed) Raven Press, New York, 193-200

Laburthe M, Mangeat P, Marchis-Mouren G, Rosselin G (1979) Activation of cyclic AMPdependent protein kinases by vasoactive intestinal peptide (VIP) in isolated intestinal cells from rat. Life Sci 25, 1931-1938

Laburthe M, Amiranoff B (1989) Peptide receptors in intestinal epithelium. In: Handbook of Physiology. The Gastrointestinal System II (Schultz SG, Maklouf GM, Rauner BB, eds) Am Physiol Soc, Bethesda, MD, ch 11, 215243

Liedtke CM, Hopfer U (1982) Mechanism of Cl translocation across small intestinal brushborder membrane. I. Absence of $\mathrm{Na}-\mathrm{Cl} \mathrm{CO}^{-}$ transport. Am J Physiol 242 (Gastrointest Liver Physio/ 5) G263-G271

Liedtke CM, Hopfer U (1982) Mechanism of Cl translocation across small intestinal brushborder membrane. II. Demonstration of $\mathrm{Cl}-$ $\mathrm{OH}$ exchange and $\mathrm{Cl}$ conductance. $A m \mathrm{~J}$ Physiol 242 (Gastrointest Liver Physiol 5) G272-G280

Mailman D (1978) Effects of vasoactive intestinal polypeptide on intestinal absorption and blood flow. J Physiol 279, 121-132

Modlin IM, Bloom SR, Michell SJ (1978) Experimental evidence for vasoactive intestinal peptide as the cause of the watery diarrhea syndrome. Gastroenterology 75, 1051-1054

Nylander O, Flemström G, Delbro D, Fandriks L (1987) Vagal influence on gastroduodenal $\mathrm{HCO}_{3}$ secretion in the cat in vivo. Am J Physiol 252 (Gastrointest Liver Physiol 15) G522G528

Prieto JC, Laburthe M, Hui Bon Hoa D, Rosselin $G$ (1981) Quantitative studies of vasoactive intestinal peptide (VIP) binding sites and VIPinduced adenosine $3^{\prime}: 5^{\prime}$-monophosphate pro- duction in epithelial cells from duodenum, jejunum, ileum, coecum, colon and rectum in the rat. Acta Endocrinol 96, 100-106

Said SI, Faloona GR (1975) Elevated plasma and tissue levels of vasoactive intestinal polypeptide in the watery-diarrhea syndrome due to pancreatic, bronchogenic and other tumors. N Engl J Med 293, 155-160

Schwartz CJ, Kimberg DV, Sheerin HE, Field M, Said SI (1974) Vasoactive intestinal peptide stimulation of adenylate cyclase and active electrolyte secretion in intestinal mucosa. $J$ Clin Invest 54, 536-544

Stewart CP, Turnberg LA (1989) A microelectrode study of responses to secretagogues by epithelial cells on villus and crypt of rat small intestine. Am J Physiol 257 (Gastrointest Liver Physiol 20) G334-G343

Stiel D, Murray DJ, Peters TJ (1984) Activities and subcellular localizations of enzymes implicated in gastroduodenal bicarbonate secretion. Am J Physiol 247 (Gastrointest Liver Physiol 10) G133-G139

Sullivan SK, Field M (1991) lon transport across mammalian small intestine. In: Handbook of Physiology. The Gastrointestinal System I (Schultz, Maklouf GM, Rauner BB, eds) Am Physiol Soc, Bethesda, MD, ch 10, 287-301

Tai YH, Decker RA (1980) Mechanisms of electrolyte transport in rat ileum. Am J Physiol 238 (Gastrointest Liver Physiol 1) G208G212

Turnberg L, Bieberdorf F, Morawski S, Fordtran $J(1970)$ Interrelationships of chloride, bicarbonate, sodium and hydrogen transport in the human ileum. $J$ Clin Invest 49, 557-567

Wu ZC, O'Dorisio TM, Cataland S, Mekhjian HS, Gaginella TS (1979) Effect of pancreatic polypeptide and vasoactive intestinal polypeptide on rat ileal and colonic water and electrolyte transport in vivo. Dig Dis Sci 24, 625-630 